\title{
PROGRAM PEMBERDAYAAN EKONOMI BAGI KAUM MUDA DI WILAYAH GERBANG KERTASUSILA
}

\author{
Taufiqurrahman, Farina Gandryani \\ Fakultas Hukum Universitas Wijaya Putra \\ taufiqurrahman@uwp.ac.id
}

\begin{abstract}
Abstrak
Suatu kenyataan bahwa meningkatnya jumlah angkatan kerja maupun jumlah penduduk yang bekerja secara faktual masih belum dapat menurunkan tingkat pengangguran secara signifikan. Kondisi ini kalau dibiarkan terus tanpa adanya upaya strategis, maka jumlah pengangguran akan semakin bertambah, khususnya pada usia produktif di kalangan kaum muda. Tujuan dari kegiatan ini adalah untuk meningkatkan kualitas hidup bagi kaum muda dan berkurangnya jumlah pengangguran. Program pemberdayaan ini dilaksanakan melalui pelatihan, bimbingan konseling dan penempatan kerja pada perusahaan-perusahaan di area Gerbang Kertasusila (Gersik, Bangkalan, Mojokerto, Surabaya dan Lamongan) yang bersedia. Hasil pelaksanaan program menunjukkan bahwa selama kurun waktu sekitar 3 tahun (tahun 2012-2015), lebih dari 2.500 kaum muda (antara umur 18-24 tahun) telah diberdayakan secara ekonomi dengan mengikutsertakan mereka dalam pelatihan, bimbingan konseling dan penempatan kerja pada 15 (lima belas) perusahaan yang menjadi mitra program pemberdayaan ini. Diharapkan program ini bisa dikembangkan lebih lanjut ke depan dengan mengikutsertakan banyak pihak dalam rangka mengurangi jumlah pengangguran bagi kaum muda di Jawa Timur.
\end{abstract}

Kata Kunci : Pemberdayaan Ekonomi, Kaum Muda, Pelatihan, Penempatan Kerja

\section{PENDAHULUAN}

Suatu kenyataan bahwa meningkatnya jumlah angkatan kerja maupun jumlah penduduk yang bekerja secara faktual masih belum dapat menurunkan tingkat pengangguran secara signifikan. Kepala Badan Pusat Statistik (BPS) Jatim, saat itu Irlan Indrocahyo, mengatakan bahwa jumlah angkatan kerja di Jatim pada Agustus 2012 mencapai 19,90 juta orang, bertambah sekitar 0,07 juta orang dibanding angkatan kerja Februari 2012 sebesar 19,83 juta orang, dan juga lebih tinggi 0,24 juta orang dibanding Agustus 2011 sebesar 19,76 juta orang.

Jumlah penduduk yang bekerja di Jatim pada Agustus 2012 mencapai 19,08 juta orang, bertambah sekitar 0,07 juta orang dibanding keadaan Februari 2012 sebesar 19,01 juta orang dan juga lebih tinggi 0,14 juta orang dibanding keadaan Agustus 2011 sebesar 18,94 juta orang. Melihat perbandingan penduduk yang bekerja pada Agustus 2012 terhadap Februari 2012, terjadi penurunan terbesar terjadi pada sektor pertanian 211,02 ribu orang. Diikuti sektor jasa kemasyarakatan, sosial dan perorangan sebanyak 166,92 ribu orang, dan sektor perdagangan 35,64 ribu orang. Sedangkan peningkatan penduduk yang bekerja terjadi pada sektor industri yang mencapai 243,30 ribu orang. Konstruksi 215,02 ribu orang, pergudangan 10,17 ribu orang dan sektor lainnya 14,85 ribu orang. Pada Agustus 2012, dari 19,08 juta orang yang bekerja, paling banyak bekerja di sektor pertanian yaitu 7,47 juta orang (atau 39,16 persen, disusul sektor perdagangan 3,83 juta 
orang atauy 20,09 persen, dan Sektor Industri 2,83 juta orang atau 14,86 persen (http://kominfo.jatimprov.go.id/read/umum/33102).

Dalam kesempatan lainnya, Kepala Dinas Tenaga Kerja, Transmigrasi dan Kependudukan Provinsi Jawa Timur menyebutkan bahwa jumlah penduduk di Jawa Timur cukup besar. Pada tahun 2013, dari hasil survey jumlah penduduk mencapai 38.052.950 jiwa lebih tinggi daripada 2011 yang mencapai 37.781 .599 jiwa (pada tahun 2012 jumlah sama dengan tahun 2013). Dari jumlah itu, penduduk usia kerja mencapai 28,53 juta (Agustus 2012), meningkat disbanding 2011 yang hanya 28,44 juta.

Sementara itu, angkatan kerja mencapai 19,90 juta (2012) naik menjadi 20,09 juta, di mana yang bekerja mencapai 19,08 juta (2012) meningkat menjadi 19,29 juta (2013). Tingkat pengangguran juga terlihat turun dari semula 819.563 (2012) menjadi 804.375 (2013). Dari jumlah itu, persentase tingkat pengangguran terbuka di Jawa Timur pada tahun 2013 sekitar 4 persen lebih rendah daripada persentase 2012 yang mencapai angka 4,12 persen. Sementara, tingkat partisipasi amngkatan kerja naik dari semula 69,62 persen (2012) menjadi 70,12 (2013).

Adanya penurunan tingkat pengangguran di Jawa Timur sekalipun tidak terlalu signifikan karena masuknya investor dalam menanamkan investasinya di Jawa Timur. Potensi besar para investor mau menanamkan investasinya di Jawa Timur tidak terlepas dari kemudahan yang diberikan kepada mereka dalam menanamkan investasinya di daerah. Untuk kepentingan itu, pemerintah berupaya menyiapkan tenaga kerja yang terampil dan siap kerja sesuai dengan kebutuhan. (https://jatim.antaranews.com/berita/117379/disnak er-jatim-klaim-turunkan-pengangguran-terbuka)

Secara nasional, jumlah angkatan kerja di Indonesia pada Agustus 2012 mencapai 118,0 juta orang, berkurang sekitar 2,4 juta orang dibanding angkatan kerja Februari 2012 sebesar 120,4 juta orang atau bertambah sekitar 670 ribu orang dibanding Agustus 2011.

Jumlah penduduk yang bekerja di Indonesia pada Agustus2012 mencapai 110,8 juta orang, berkurang sekitar 2,0 juta orang dibanding keadaan pada Februari 2012 sebesar 112,8 juta orang atau bertambah 1,1 juta orang dibanding keadaan Agustus 2011.

Tingkat Pengangguran Terbuka (TPT) di Indonesia pada Agustus 2012 mencapai 6,14 persen, mengalami penurunan dibanding TPT Februari 2012 sebesar 6,32 persen dan TPT Agustus 2011 sebesar 6,56 persen.

Selama setahun terakhir (Agustus 2011-Agustus 2012), jumlah penduduk yang bekerja mengalami kenaikan terutama di Sektor Industri sekitar 830 ribu orang (5,71 persen), serta Sektor Jasa Kemasyarakatan sebesar 450 ribu orang (2,70 persen). Sedangkan sektor-sektor yang mengalami penurunan adalah Sektor Pertanian sebesar 450 ribu orang (1,14 persen), Sektor Perdagangan sebesar 250 ribu orang (1,07 persen), dan Sektor Transportasi, Pergudangan, dan Komunikasisebesar 80 ribu orang (1,57 persen).

Berdasarkan jumlah jam kerja pada Agustus 2012, sebesar 76,5 juta orang (69,04 persen) bekerja diatas 35 jam per minggu, sedangkan penduduk bekerja dengan jumlah jam kerja kurang dari 15 jam perminggu mencapai 6,6 juta orang (5,98 persen).

Pada Agustus 2012, penduduk bekerja pada jenjang pendidikan SD ke bawah masih tetap mendominasi yaitu sebesar 53,9 juta orang (48,63persen), sedangkan penduduk bekerja dengan pendidikan diploma sekitar 3,0 juta orang $(2,68$ persen) dan penduduk bekerja dengan pendidikan universitas hanya sebesar 7,0 juta orang (6,30persen)

(https://www.bps.go.id/pressrelease/2012/11/05/65/ pada-agustus-2012--tingkat-pengangguran-terbuka-tpt--sebesar-6-14-persen.html)

Kondisi obyektif tentang tidak menurunnya secara signifikan jumlah pengangguran di Jawa Timur inilah yang merupakan salah satu pertimbangan PLAN Indonesia untuk melaksanakan program Pemberdayaan Ekonomi Kaum Muda/Youth Economic Empowering (PEKM/YEE) di wilayah Gersik, Bangkalan, Mojokerto, Surabaya dan Lamongan (Gerbang Kertasusila).

Ekonomi, Sosial, dan Budaya

1409 


\section{METODE}

Pemberdayaan ekonomi bagi kaum muda ini dilakukan melalui pelatihan, bimbingan konseling dan penempatan kerja pada perusahaanperusahaan di area Gerbang Kertasusila.

\section{HASIL DAN PEMBAHASAN}

\section{Perencanaan dan Pengorganisasian}

Sebagai langkah awal pelaksanaan, dilakukan penandatanganan kontrak kerjasama antara KADIN Jatim dengan PLAN Indonesia sebagaimana tertuang dalam sebagaimana tertuang dalam Perjanjian Kemitraan No. 023/Contract/FY13/Plan/CO/XI/2012 tertanggal 21 November 2012.

Dipilihnya KADIN Jatim oleh PLAN Indonesia sebagai mitra dalam program PEKM/YEE ini didasarkan pada pertimbangan bahwa KADIN Jatim merupakan salah satu institusi yang mempunyai jaringan advokasi ke pemerintah selaku pemilik kebijakan dan wewenang, mempunyai jaringan yang luas dengan perusahaan yang nantinya akan menjadi tempat asessmen kaum muda kurang beruntung yang direkut. Selain itu, KADIN Jatim memiliki lembaga dan gedung yang representatif untuk pengembangan potensi pemuda dan kewirausahaan, yaitu KADIN INSTITUTE. Berdasarkan beberapa pertimbangan tersebut pada akhirnya PLAN Indonesia memilih KADIN Jatim sebagai mitra untuk melaksanakan Program PEKM/YEE selama 3 (tiga) tahun yakni mulai bulan November 2012 sampai April 2015 dengan target 2500 Pemuda.

Bagi KADIN Jatim sendiri, kesediaan menerima program ini didasarkan pada pertimbangan strategis, yaitu adanya tali benang merah dengan Visi dan Misi KADIN Jatim itu sendiri. Visi KADIN Jatim adalah "Menjadi komponen penting dalam peningkatan daya saing ekonomi Jatim". Visi ini tidak lepas dari visi besar dari KADIN Indonesia sendiri, yaitu "Mewujudkan dunia usaha nasional yang kuat, berdaya cipta dan berdaya saing tinggi, dalam wadah kadin yang profesional di seluruh tingkat".

Selanjutnya, visi tersebut secara operasional dijabarkan ke dalam Misi KADIN Jatim yang dirumuskan sebagai berikut : a) Terbentuknya lingkungan bisnis yang sehat; b) Mendorong peningkatan Produk Domestik Regional Bruto (PDRB) Jatim; c) Menimbulkan peningkatan pasar lokal, nasional dan ekspor; d) Timbulnya entrepreneur.

Sekalipun dalam misi KADIN Jatim tidak dirumuskan secara eksplisit tentang program pemberdayaan kaum muda, tetapi hal ini tidak berarti keberadaan program PEKM/YEE yang diselenggarakan oleh PLAN Indonesia ini tidak mendapatkan tempat pada misi KADIN Jatim. Program PEKM/YEE ini memiliki keterkaitan erat dengan rumusan misi KADIN Jatim, yaitu munculnya entrepenur baru.

Munculnya entreprenur baru di Jatim merupakan salah satu misi KADIN Jatim. Namun demikian, disadari bahwa untuk mrealisasikan misi tersebut tidak mudah. Salah satu kendala dalam upaya merealisasikan misi tersebut adalah masih kuatnya paradigma mencari pekerjaan daripada menjadi entrepreneur. Karenanya, target membuka lapangan pekerjaan bagi kaum muda merupakan pintu masuk dan sekaligus sebagai target antara menuju teraktualisasinya misi penciptaan entreprenur baru. Karenanya, dalam pelatihan YEE, calon tenaga kerja selain diberi pembekalan materi teknis terkait dengan bidang usaha yang akan digelutinya, juga diberi materi-materi yang bersifat provokatif untuk tidak hanya berhenti sebagai tenaga kerja, lebih dari itu yaitu menciptakan lapangan kerja. Dalam konteks ini, program PEKM/YEE memiliki keterkaitan yang erat dengan misi KADIN Jatim keempat, yaitu mendorong timbulnya entrepreneur. Karenanya, peluang yang diberikan oleh PLAN Indonesia untuk bekerjasama dalam mengurangi jumlah pengangguran kaum muda melalui Program PEKM/YEE ini tidak dilewatkan begitu saja.

Sebagai tindak lanjut dari perjanjian kerjasama yang telah dibuat dan ditandatangani oleh dan antara KADIN Jawa Timur dengan Plan Indonesia, secara internal di KADIN Jatim dibentuk Tim Pengarah dan Tim Teknis sebagai Pengelola Program PEKM/YEE melalui Surat Keputusan Dewan Pengurus KADIN JATIM No. 513/K/SKEP-DP/IX/2012 tertanggal 16 Oktober 2012.

Selain itu, dalam rangka untuk melakukan tracking di lapangan, khususnya untuk mendapatkan informasi tenaga kerja yang masih aktif bekerja dan

Ekonomi, Sosial, dan Budaya

1410 
yang telah berhenti bekerja, direkrut tracker sebanyak 6 (enam) orang, masing-masing : 1) untuk wilayah Sidoarjo dan sekitarnya); 2) untuk wilayah Surabaya dan sekitarnya); 3) untuk wilayah Gresik dan sekitarnya); 4) untuk wilayah Mojokerto dan sekitarnya); 5) untuk wilayah Bangkalan dan sekitarnya); 6) untuk wilayah Surabaya dan sekitarnya).

Struktur Tim Teknis terdiri atas Direktur Program, Manajer Rekruitmen, Manajer Pelatihan yang dibantu dengan Asisten Manajer Umum, Manajer Penempatan Kerja dan manajer Administrasi \& Keuangan yang dibantu dengan Asisten Manajer Administrasi dan Assisten Manajer Keuangan.

Sesuai dengan organ yang ada dalam Tim Teknis tersebut, ada 3 aktifitas besar yang harus dilakukan oleh tim ini, yaitu : pertama, melakukan rekruitmen terhadap kelompok sasaran atau pemanfaat program (dalam hal ini para kawula muda sebagai calon tenaga kerja); kedua, melakukan pelatihan; dan ketiga, menyalurkan kelompok sasaran yang telah dilatih kepada mitra kerja (dalam hal ini perusahaan yang telah bersepakat dengan Tim Pengelola untuk menerima sebagai tenaga kerja).

Khusus terkait dengan pelaksanaan pelatihan, sesuai dengan aturan yang berlaku di internal PLAN Indonesia, tenaga instruktur pelatihan tidak boleh berasal dari tim teknis. Berdasarkan hal tersebut, dalam rangka memiliki tenaga fasilitator sendiri yang bisa didayagunakan sewaktu-waktu sesuai dengan kebutuhan, maka dilakukan pelatihan Training of Trainer. Penyelenggaraan pelatihan TOT ini dilaksanakan selama 5 hari, yaitu tanggal 18-22 Februari 2013 bekerjasama dengan Today Solution berdasarkan Perjanjian Kerjasama Penyelenggaraan Training of Trainer No. 007/A/TODAYSOLUTION/II/2013, No. $012 / \mathrm{K} / \mathrm{MoU} / \mathrm{KJT}-\mathrm{PI} / \mathrm{II} / 2013$ tertanggal 14 Februari 2013.

Beberapa instruktur hasil dari pelatihan TOT dan instruktur lainnya (baik dari Asosiasi Persepatuan Indonesia (APRESINDO), PT. Midi Utama Indonesia, LKP Rahayu Art \& Design, Nusantara Handycraft) yang terlibat dalam pelaksanaan Pelatihan YEE sejumlah 39 (tiga puluh Sembilan) orang sebagai tenaga instruktur.

\section{Pelaksanaan}

Sebagai aktualisasi dari program pemberdayaan ekonomi ini, dilakukakan beberapa kegiatan utama, yaitu : a) sosialisasi, b) rekrutmen, c) pelatihan, d) penempatan kerja, dan e) monitoring.

\section{2.a. Kegiatan Sosialisasi}

Sistem yang digunakan dalam melaksanakan Sosialisasi adalah sebagai berikut :

1) Pemetaan Kaum Muda sebagai kelompok sasaran, yaitu :

- Mendatangi basis kaum muda (Karang taruna, Remaja masjid, Pondok Pesantren Dll);

- Membuat jadwal pertemuan dengan kaum muda.

2) Persyaratan yang harus dipenuhi oleh kelompok sasaran sebagai berikut :

- Berusia 15-24 tahun berstatus lajang, menikah atau cerai;

- Diutamakan untuk perempuan dengan perbandingan 80:20 terhadap kaum muda laki-laki;

- Putus sekolah atau tamatan SD/SMP/SMU;

- Tidak sedang bekerja atau bekerja di sektor informal;

- Berasal dari keluarga yang masuk kategori kurang mampu.

- Tinggal di wilayah Gerbang Kertasusila

3) Penjelasan :

- Menjelaskan apa itu PLAN dan bergerak dalam bidang apa;

- Menjelaskan mengenai visi, misi dan kegiatan-kegiatan dalam program PEKM/YEE;

- Menjelaskan bagaimana cara bergabung dengan YEE dan apa saja kriteria untuk bisa bergabung;

- Menginformasikan tempat-tempat yang dapat didatangi oleh kaum muda yang ingin bergabung dalam program PEKM/YEE;

- Menjelaskan peluang-peluang yang dimiliki bagi kaum muda yang bergabung dalam program PEKM/YEE, termasuk dan tidak terbatas pada rekrutmen oleh perusahaan- 
perusahaan yang telah bermitra dengan KADIN-PLAN.

4) Pendataan

Pendataan dilakukan guna mendapatkan jumlah peserta yang berminat untuk bergabung mengikuti program YEE sekaligus menyaring peserta sesuai kualifikasi yang sudah ditentukan mulai dari Usia, pendidikan dan jenis kelamin yang nantinya data ini akan digunakan untuk menyiapkan tahapan selanjutnya oleh Tim Pelaksana agar pelaksanaan pelatihan berjalan dengan lancar dan sukses.

5) Konseling Karier

Konseling karier dilaksanakan untuk mengetahui minat dan bakat serta kesiapan mental peserta dalam menghadapi dunia kerja dalam bentuk pemberian pengarahan bersifat monolog dan dialog terhadap peserta kaum muda sehingga nantinya setelah penempatan diharapkan dapat menapaki jenjang karir dengan baik serta dapt mengurangi angka drop out.

Kegiatan sosialisasi ini dilaksanakan oleh KADIN-PLAN bersama-sama dengan perusahaan mitra yang terjaring melakukan sosialisasi ke daerah-daerah terutama di daerah sekitar perusahaan berdomisili. Dalam aktifitas ini, peran KADIN Jatim memfasilitasi pertemuan Tim KADIN-PLAN untuk dengan jaringan KADIN Jatim, termasuk dan tidak terbatas dengan PT. Alfamidi Utama Indonesia dan perusahaan-perusahaan di Jawa Timur yang merupakan anggota KADIN Jatim.

Dalam perjalanan sosialisasi yang dilaksanakan oleh KADIN-PLAN dan Perusahaan Mitra, animo peserta sangat luar biasa untuk bisa bergabung dan mengikuti program YEE, 2500 pemuda merupakan angka yang sangat kecil dibandingkan dengan antusiasme para peserta sosialisasi program.

Sosialisasi juga dilaksanakan untuk mendapatkan perusahaan mitra yang nantinya akan dijadikan penempatan kerja bagi peserta yang sudah bergabung dalam program YEE, dari sekian banyak perusahaan yang didatangi serta mengajukan perusahaannya sebagai perusahaan mitra KADINPLAN, terjaring sebanyak 15 (lima belas) perusahaan yang memenuhi standar kualifikasi yang sudah ditentukan oleh KADIN-PLAN.
Kelima belas perusahaan yang terjaring sebagai mitra dalam program ini adalah sebagai berikut :

Tabel 1. Perusahaan Mitra Berdasarkan
Bidang Usaha dan Lokasi

\begin{tabular}{|l|l|l|l|}
\hline No & Nama Perusahaan & Lokasi & $\begin{array}{l}\text { Bidang } \\
\text { Usaha }\end{array}$ \\
\hline 01 & $\begin{array}{l}\text { PT. Intidragon } \\
\text { Suryatama }\end{array}$ & Mojokerto & $\begin{array}{l}\text { Upper Shoe } \\
\text { Sewing }\end{array}$ \\
\hline 02 & $\begin{array}{l}\text { PT. Young Tree } \\
\text { S3 }\end{array}$ & Sidoarjo & $\begin{array}{l}\text { Upper Shoe } \\
\text { Sewing }\end{array}$ \\
\hline 04 & UD. Danapaksi & Sidoarjo & $\begin{array}{l}\text { Upper Shoe } \\
\text { Sewing }\end{array}$ \\
\hline 05 & $\begin{array}{l}\text { PT. Terus Makmur } \\
06\end{array}$ & $\begin{array}{l}\text { Putra Mandiri } \\
\text { Surabaya }\end{array}$ & $\begin{array}{l}\text { Upper Shoe } \\
\text { Sewing }\end{array}$ \\
\hline 07 & $\begin{array}{l}\text { PT. Widaya Inti } \\
\text { Plasma }\end{array}$ & Sidoarjo & $\begin{array}{l}\text { Upper Shoe } \\
\text { Sewing }\end{array}$ \\
\hline 08 & $\begin{array}{l}\text { LKP. Rahayu Art \& } \\
\text { Design }\end{array}$ & Sidoarjo & Batik Tidie \\
\hline 09 & $\begin{array}{l}\text { PT. Midi Utama } \\
\text { Indonesia }\end{array}$ & Sidoarjo & Retail \\
\hline 10 & $\begin{array}{l}\text { PT. Bukit Darmo } \\
\text { Golf }\end{array}$ & Surabaya & Caddy \\
\hline 11 & UKM Pelepah pisang & Gresik & $\begin{array}{l}\text { Pengrajin } \\
\text { Indonesia }\end{array}$ \\
\hline 12 & $\begin{array}{l}\text { PT. Sukses Jaya } \\
\text { Abadi }\end{array}$ & Mojokerto & $\begin{array}{l}\text { Upper Shoe } \\
\text { Sewing }\end{array}$ \\
\hline 13 & UD. Rukun Jaya & Surabaya & Asembling \\
\hline 14 & $\begin{array}{l}\text { PT. Kharisma Baru } \\
\text { Handicraft }\end{array}$ & Nganjuk & $\begin{array}{l}\text { Upper Shoe } \\
\text { Sewing }\end{array}$ \\
\hline 15 & Sidoarjo & $\begin{array}{l}\text { Ribbon } \\
\text { Embroidery }\end{array}$ \\
\hline
\end{tabular}

Sebagaimana telah diuraikan sebelumnya bahwa program ini diprioritaskan bagi calon tenaga kerja yang ada di wilayah Gerbang Kertasusila. Namun dalam kenyataannya sebagaimana terlihat pada tabel di atas, ada satu perusahaan mitra yang tidak berada di wilayah Surabaya Dan sekitarnya, yaitu PT. Kharisma Baru Indonesia yang Ekonomi, Sosial, dan Budaya

1412 
berkedudukan di Nganjuk. Sekalipun perusahaan ini berada di Nganjuk, tetapi proses rekrutmen awal, mulai dari pendaftaran sampai pada seleksi administratif, semua dilakukan di PT. Rajapaksi Adyaperkasa di Sidoarjo. Namun, karena ternyata pendaftar program PEKM/YEE hampir sebagian besar berasal dari Nganjuk sekalipun proses pendaftaran dilakukan di Sidoarjo, maka dengan segala keterpaksaan Tim KADIN-PLAN mengambil kebijakan untuk mengaktualisasikan keinginan para kawula muda untuk bergabung dalam program YEKM/YEE.

\section{2.b. Kegiatan Rekruitmen}

Selama pelaksanaan program PEKM/YEE, rekrutmen kawula muda sebagai calon tenaga kerja tidak dilakukan secara murni sendirian oleh Tim KADIN-PLAN. Rekrutmen dilakukan secara bersama oleh Tim KADIN-PLAN dengan Perusahaan Mitra dengan kualifikasi-kualifikasi yang sudah disepakati bersama.

Rekrutmen yang dilakukan meliputi seleksi administratif dan seleksi wawancara. Seleksi wawancara harus dilakukan untuk mengetahui keseriusan mereka untuk bergabung dalam program YEKM/YEE. Sekalipun demikian, seleksi ini tidak menjamin sepenuhnya bahwa peserta yang lolos untuk bergabung dalam program ini dengan mengikuti pelatihan dan sekaligus ditempatkan pada perusahaan di mana mereka mengajukan pendaftaran pada akhirnya mereka tidak drop-out.

Sebagaimana telah diuraikan sebelumnya, ternyata usia merupakan salah satu faktor penting dalam menjaga keberlangsungan seseorang untuk berkiprah dalam dunia kerja. Semakin matang atau dewasa seseorang yang terlibat dalam program PEKM/YEE, mereka semakin bertanggung-jawab atas pekerjaan yang diembannya, baik dalam kerangka pribadi, keluarga maupun lingkungan masyarakat.

\section{2.c. Kegiatan Pelatihan}

Pelatihan hard-skill yang dilaksanakan oleh KADIN-PLAN dengan mitra adalah sesuai kebutuhan perusahaan mitra yang mana bergerak dalam beberapa bidang, sehingga pelatihan hard skill antara perusahaan mitra satu dengan yang lainnya akan berbeda sesuai bidangnya masingmasing, namun dalam pelaksanaan pelatihan hard skill ini KADIN-PLAN menerapkan metode pelatihan yang cukup sesuai guna menopang kebutuhan perusahaan akan sumber daya manusia yakni dengan cara menggelar pelaksanaan pelatihan di tempat produksi atau tempat kerja perusahaan dengan harapan peserta dapat menyesuaikan diri dengan dunia pekerjaan yang sesungguhnya dan produktifitas cukup tinggi, dibandingkan dengan metode pelatihan yang pelaksanaan pelatihannya terpisah dengan tempat kerja yang mana sering terjadi situasi tidak sesuai antara materi yang diberikan saat pelatihan dengan situasi yang terjadi di dunia kerja sesungguhnya, sehingga hali ini akan menjadi permasalahan tersendiri yang dapat mengakibatkan mental peserta pelatihan mengalami tekanan serta dapat mengurangi produktifitas itu sendiri.

Pelatihan hard skill merupakan hal yang mendasar untuk membekali keahlian para peserta dalam menjalani aktivitas pekerjaan nantinya, namun ada hal lain yang juga cukup penting untuk diberikan pada peserta guna menjalani aktifitas pekerjaan agar siap secara mental dan berhasil menapaki jenjang karir yang ada serta sukses dalam kehidupan sehari-harinya, materi yang dimaksut adalah pelatihan soft skill.

Selama dalam pelaksanaan program PEKM/YEE telah dilakukan pelatihan kerja sebanyak 50 (lima puluh) kali pelatihan dari 15 (lima belas) perusahaan sebagai mitra KADINPLAN. Dari pelatihan tersebut, kaum muda yang berhasil dilatih dan sekaligus ditempatkan sebanyak 2.500 orang. Adapun rincian pelatihan tersebut sebagai berikut :

Dalam pelatihan soft-skill ini terdapat 3 (tiga) materi yang disampaikan, yakni sebagai berikut :

\section{2.c.1. Materi Gender}

Materi gender ini membahas tentang jenis kelamin sosial atau status kelamin sosial beserta isuisu yang tengah ramai diperbincangkan oleh masyarakat luas, membahas tentang peran dan tanggung jawab antara laki-laki dan perempuan sehingga dapat hidup berdampingan dengan harmonis tanpa ada perlakuan diskriminasi terhadap salah satu pihak, yang mana dalam menyampaikan

$$
\text { Ekonomi, Sosial, dan Budaya }
$$


materi gender ini pemateri atau trainer kami menggunakan beberapa macam tehnik penyampaian dengan tujuan materi gender yang disampaikan akan lebih mengena dan dapat diserap oleh peserta.

Tampilan slide masih selalu digunakan dalam pemaparan materi yang dikemas semenarik mungkin agar peserta antusias untuk menerima materi gender ini, tentunya slide ini banyak berisikan gambar-gambar informatif mengenai pendidikan gender.

Penyampaian meteri secara role play digunakan oleh trainer Kadin-Plan untuk merangsang peserta mempraktekkan apa yang sudah diterima dari materi yang disampaikan, sehingga peserta paham akan contoh isu-isu dan hal-hal yang berkaitan dengan jender ataupun kesetaraan jender. Namun trainer gender KADIN-PLAN sudah memilah-milah materi mana yang akan disampaikan berdasarkan beberapa aspek dan pertimbangan kejiwaan, sosio kultural dari peserta yang akan menerima materi gender.

Video visual juga digunakan sebagai salah satu tehnik untuk menyampaikan materi ke peserta serta untuk memberikan gambaran yang lebih nyata mengenai contoh permasalahan gender sehingga penyampaian materi tidak terkesan membosankan.

Penyampaian materi gender ini dilaksanakan dalam durasi 12 jam yang dilaksanakan dalam kurun waktu 2 hari.

\section{2.c.2. Materi Pengelolaan Keuangan}

Materi Pengelolaan keuangan ini merupakan materi yang membahas tentang bagaimana cara mengelolah uang secara sederhana dan tidak rumit. Membahas dasar-dasar :

- Bagaimana cara mengelola keuangan ?

- Bagaimana cara mengelola sumber pendapatan?

- Bagaimana cara mengelolah pengeluaran?

Materi ini disampaikan dengan harapan peserta kaum muda bisa mengelolah keuangan pribadinya mengingat mayoritas peserta adalah baru mengenal dunia kerja yang mana sebelumnya masih berkecimpung dalam dunia pendidikan sehingga pengetahuan dalam pengelolaan keuangan masih minim, harapan selanjutnya setelah peserta dapat mengolah keuangan adalah mampu memberdayakan perekonomian dirinya sendiri dan perekonomian keluarga.

Sistem penyampaian dengan slide digunakan dalam pemaparan materi yang dikemas semenarik mungkin agar peserta antusias untuk menerima materi pengolahan gender ini, tentunya slide ini banyak berisikan gambar-gambar informatif mengenai pengolahan keuangan sederhana.

Penyampaian meteri secara role-play digunakan oleh trainer Kadin-Plan untuk merangsang peserta mempraktekkan apa yang sudah diterima dari materi yang disampaikan, sehingga peserta paham akan contoh isu-isu dan hal-hal yang berkaitan dengan pengelolaan keuangan. Praktik pembuatan buku catatan keuangan secara sederhana juga diajarkan secara langsung, sehingga trainer bisa mengoreksi hasil kerjaan para peserta.

Penyampaian materi pengelolaan keuangan ini dilaksanakan dalam durasi 12 jam yang dilaksanakan dalam kurun waktu 2 hari.

\section{2.c.3. Materi Pembentukan Karakter}

Materi pembentukan karakter merupakan materi yang berisikan motifasi untuk membentuk karakter kaum muda agar siap menghadapi situasi dan suasana dunia kerja secara mental. Materi karakteer building ini juga membekali peserta dengan pembentukan karakter untuk individu masing sebagai bentuk refleksi dan renungan atas kehidupan sehari-hari terhadap orang tua, keluarga, dan lingkungan sekitar serta lingkungan kerja.

Diharapkan peserta dapat mengembangkan potensi yang ada dalam dirinya serta dapat menjalankan peran dalam pekerjaannya semaksimal mungkin dan dapat menimbulkan rasa tanggungjawab pada diri masing-masing.

Pembahasan mengenai apa itu bekerja?, bagaimana bekerja dengan hati sehingga dapat memahami makna bekerja yang sebenarnya yang akan memberikan dampak positif pada perusahaan dalam peningkatkan produktifitas.

Penyampaian materi pembentukan karakter ini dilaksanakan dalam durasi 12 jam yang dilaksanakan dalam kurun waktu 2 hari.

$$
\text { Ekonomi, Sosial, dan Budaya }
$$




\section{2.d. Kegiatan Penempatan Kerja}

Penempatan dilakukan sesuai kebutuhan di perusahaan dengan sistem kontrak minimal kerja di perusahaan selama 1 tahun dan kesepakatan untuk penempatan peserta di perusahaan mitra ini dituangkan dalam kesepakatan bersama berupa Memorandum of Understanding (MOU) antara KADIN-PLAN dengan Perusahaan Mitra, penempatan dilaksanakan setelah pelatihan hard skill dan soft skill terselesaikan, sehingga semua peserta yang direkrut bisa ditempatkan keseluruhan di perusahaan mitra.

Hal ini disambut baik oleh perusahaan mitra mengingat untuk melatih skill pemula serta mengikat peserta agar bertahan dalam perusahaan dalam waktu yang cukup lama sangatlah sulit, mengingat mayoritas Perusahaan Mitra KADINPLAN merupakan perusahaan padat karya yang mana karyawan akan sering keluar dan masuk dengan berbagai macam alasan.

Mengingat keharusan Perusahaan Mitra untuk merekrut calon tenaga kerja yang telah dilatih dalam pelatihan yang dilaksanakan oleh KADINPLAN merupakan 1 (satu) paket yang dituangkan dalam MOU yang telah ditandangani sebelumnya oleh Perusahaan Mitra dengan KADIN-PLAN, maka sangat rasional dan wajar kalau antara jumlah pemuda yang ikut pelatihan dengan jumlah pemuda yang ditempatkan di Perusahaan Mitra jumlahnya sama.

Tabel 2. Jumlah Kawula Muda yang Ikut Pelatihan Dan Penempatan Kerja Berdasarkan Jenis Kelamin

\begin{tabular}{|c|l|l|l|l|}
\hline No. & $\begin{array}{l}\text { Nama Perusahaan } \\
\text { Mitra }\end{array}$ & $\begin{array}{l}\text { Pel \& Prp } \\
\text { Pen }\end{array}$ & Lk \\
\hline 1 & $\begin{array}{l}\text { PT. Intidragon } \\
\text { Suryatama, Mjkt }\end{array}$ & 150 & 150 & - \\
\hline 2 & $\begin{array}{l}\text { PT. Young Tree, } \\
\text { Sidoarjo }\end{array}$ & 100 & 100 & - \\
\hline 3 & $\begin{array}{l}\text { PT. Rajapaksi } \\
\text { Adyaperkasa, Sdj }\end{array}$ & 717 & 558 & 159 \\
\hline 4 & $\begin{array}{l}\text { UD. Danarta, } \\
\text { Mojokerto }\end{array}$ & 15 & 4 & 11 \\
\hline 5 & $\begin{array}{l}\text { CV. Terus Makmur, } \\
\text { Surabaya }\end{array}$ & 56 & 56 & - \\
\hline 6 & $\begin{array}{l}\text { CV. Putra Mandiri, } \\
\text { 2V }\end{array}$ & 25 & - \\
\hline
\end{tabular}

\begin{tabular}{|c|c|c|c|c|}
\hline & Mojokerto & & & \\
\hline 7 & $\begin{array}{l}\text { PT. Widaya } \\
\text { Plasma, Sdj }\end{array}$ & 40 & 40 & \\
\hline 8 & $\begin{array}{l}\text { CV. Rahayu Art \& } \\
\text { Design, Sdj }\end{array}$ & 126 & 114 & 12 \\
\hline 9 & $\begin{array}{l}\text { PT. Midi Utama } \\
\text { Indonesia, Sdj }\end{array}$ & 799 & 413 & 386 \\
\hline 10 & $\begin{array}{l}\text { PT. Bukit Darmo } \\
\text { Golf, Sby }\end{array}$ & 31 & 31 & - \\
\hline 11 & $\begin{array}{l}\text { UKM Pelepah } \\
\text { Pisang, Gresik }\end{array}$ & 41 & 41 & - \\
\hline 12 & $\begin{array}{ll}\text { PT. Sukses Jaya } \\
\text { Abadi, Mjkt }\end{array}$ & 32 & 32 & - \\
\hline 13 & UD. Rukun Jaya, Sby & 19 & 14 & 5 \\
\hline 14 & $\begin{array}{l}\text { PT. Kharisma Baru } \\
\text { Indonesia, Sdj }\end{array}$ & 300 & 300 & - \\
\hline 15 & $\begin{array}{l}\text { UD. Nusantara } \\
\text { Handycraft, Sdj }\end{array}$ & 49 & 45 & 4 \\
\hline & TOTAL & 2500 & 1923 & 577 \\
\hline & Prosentase & 100 & 77 & 23 \\
\hline
\end{tabular}

\section{2.d.1. Pemenuhan Target $80 \%$ Perempuan}

Sejak awal, telah disepakati bersama bahwa peserta yang harus bisa dilatih dan ditempatkan pada perusahaan mitra sebanyak 2500 orang tenaga kerja dengan perbandingan jumlah perempuan-lakilaki 80 : 20. Dengan komposisi ini, berarti jumlah perempuan yang harus berhasil dilatih dan ditempatkan sebagai tenaga kerja sebanyak 80 orang dan jumlah laki-laki sebanyak 500 orang.

Target angka tersebut tidak mudah untuk dicapai. Tim Teknis KADIN-PLAN telah berapaya keras dan melakukan strategi tersendiri, mulai dari sosialisasi awal ke kaum muda dan sosialisasi ke perusahaan disampaikan dari awal bahwa dalam program ini diutamakan $80 \%$ perempuan, sehingga jika nantinya jika peserta laki-laki peminat program PEKM/YEE melebihi kuota 20\% maka disarankan kepada perusahaan mitra agar tetap menerima peserta laki-laki, namun dengan catatan semuanya tidak berada dalam kerjasama dengan KADINPLAN. Kualifikasi dan pembatasan dari awal inilah salah satu strategi yang sangat efisien untuk memenuhi target $80 \%$ peserta dari kaum perempuan.

Data yang ada menunjukkan bahwa target $80 \%$ jumlah perempuan yang berhasil dilatih dan ditempatkan sebagai tenaga kerja belum terpenuhi,

Ekonomi, Sosial, dan Budaya 
yaitu sebanyak 1923 orang atau sebanyak $77 \%$. Sekalipun dari sisi angka prosentase tidak terpenuhi, tetapi yang menggembirakan bahwa jumlah target perolehan jumlah tenaga kerja yang berhasil direkrut secara keseluruhan sebesar 2500 orang tercapai.

\section{2.d.2. Pemenuhan Target Kelompok Marginal}

Mayoritas peserta pemanfaat program YEE ini berasal dari kelompok marginal dilihat dari segi pendidikan mereka yang rata-rata hanya tamatan SMP, Putus sekolah SMA, bahkan mereka ada yang hanya lulusan SD yang mana mereka juga sangat sulit mendapatkan informasi mengenai lowongan pekerjaan, baik informasi dari media cetak maupun media elektronik. Kaum marginal inilah yang menjadi target utama Kadin-Plan dalam memenuhi angka 2500 dalam kurun waktu November 2012 sampai April 2015. Namun beberapa perusahaan mitra juga ada yang hanya mau menerima peserta program dengan kualifikasi pendidikan minimal SMA, semisal PT. Midi Utama Indonesia Tbk dan Bukit Darmo Golf.

\section{2.e. Kegiatan Monitoring}

Pengawasan dilakukan setelah semua tahapan mulai sosialisasi, rekruitmen dan pelatihan serta placemen selesai, pengawasan ini dilaksanakan untuk mengetahui up-date perkembangan terbaru mengenai keadaan peserta program YEE yang ada di perusahaan maupun peserta program YEE yang sudah keluar dari perusahaan (drop-out).

Pengawasan terhadap peserta yang masih bertahan lebih bertujuan untuk mengetahui perkembangan kenaikan pendapatan dan indeks kemiskinan yang mana pengawasan ini dilaksanakan setiap 6 bulan sekali, sehingga dapat diketahui pergerakan perkembangan pendapatan peserta program terutama perbedaan keadaan perekonomian sebelum bergabung dengan program YEE dan keadaan perekonomian setelah bergabung dengan program YEE. Setelah diketahui perkembangan tentang peserta program YEE, maka pengawasan juga berfungsi untuk mengukur tingkat kemakmuran perekonomian keluarga dari peserta program YEE, apakah ada perubahan yang positif setelah salah satu anggota keluarganya menjadi peserta program YEE. Pengawasan ini dilaksanakan dengan cara mendatangi perusahaan mitra peserta program dan bertemu langsung dengan peserta program YEE, bahkan Kadin-Plan juga sering berkunjung ke tempat tinggal peserta untuk mendapatkan informasi yang lebih detail mengenai perkembangan peserta di lingkungan keluarga.

Pengawasan juga dilaksanakan kepada peserta program YEE yang drop-out, pengawasan ini guna mendapatkan informasi mengenai alasan mereka drop-out dari perusahaan penempatan setelah pelatihan, keadaan peserta setelah drop-out apakah sudah mendapatkan kerja di perusahaan yang baru atau masih dalam keadaan belum mendapatkan pekerjaan. Bagi peserta drop out yang sudah mendapatkan pekerjaan lain, maka akan didapatkan informasi perkembangan pendapatan antara perusahaan yang lama dengan perusahaan yang baru. Namun bagi peserta drop-out yang belum mendapatkan pekerjaan lain, maka akan diberikan tawaran informasi lowongan pekerjaan lain di perusahaan mitra Kadin-Plan yang membutuhkan. Pelaksanaan pengawasan ini juga dilaksanakan dengan cara mengunjungi tempat tinggal peserta program YEE.

Penelusuran angka Drop-Out (DO) dari tenaga kerja yang telah terserap dalam dunia kerja (dalam hal ini Perusahaan Mitra) dilakukan dengan melakukan tracking langsung ke lapangan berdasarkan informasi yang didapatkan dari masingmasing perusahaan mitra. Tracking dilakukan oleh beberapa personil yang telah direkrut dan diangkat secara khusus untuk tugas-tugas tersebut.

Beberapa perusahaan mitra yang telah memberikan informasi tentang tenaga kerja yang DO adalah : CV. Terus Makmur (TM) sebanyak 40 orang, UKM Pelepah Pisang (UKM) sebanyak 30 orang, PT. Rajapaksi Adyaperkasa (RAP) sebanyak 283 orang, PT. Inti Dragon Surya Perkasa (IDS) sebanyak 108 orang, PT. Bukit Darmo Golf (BDG) sebanyak 30 orang, PT. Young Tree (YT) sebanyak 66 orang, LKP Rahayu Art \& Design (LKP) sebanyak 21 orang PT. Prima Mandiri (PM) sebanyak 24 orang, PT. Widaya Inti Plasma (WIP) sebanyak 20 orang. Dengan demikian, tracking dilakukan terhadap tenaga kerja yang untuk

$$
\text { Ekonomi, Sosial, dan Budaya }
$$


sementara dianggap sebagai tenaga kerja DO sebanyak 622 (enam ratus dua puluh dua) orang.

Dari hasil penelusuran tracking di lapangan terhadap 622 orang tersebut, didapatkan informasi bahwa tenaga kerja yang betul-betul DO sebanyak 368 (tiga ratus enam puluh delapan) orang, selebihnya yaitu masih aktif bekerja sebanyak 77 (tujuh puluh tujuh) orang dan tracking yang invalid sebanyak 177 (seratus tujuh puluh tujuh) orang. Jumlah yang DO tersebut tersebar ke dalam 9 perusahaan mitra, yaitu : TM sebanyak 30 orang, UKM sebanyak 28 orang, RAP sebanyak 140 orang, IDS sebanyak 81 orang, BDG sebanyak 0 orang, YT sebanyak 31 orang, LKP sebanyak 18 orang, PM sebanyak 24 orang dan WIP sebanyak 16 orang.

\section{KESIMPULAN}

Hasil pelaksanaan program PEKM/YEE selama kurun waktu sekitar 3 tahun (tahun 20122015) ini secara nyata telah memberikan manfaat yang besar bagi masyarakat, yaitu lebih dari 2.500 kaum muda (antara umur 18-24 tahun) telah diberdayakan secara ekonomi dengan mengikutsertakan mereka dalam pelatihan, bimbingan konseling dan penempatan kerja pada 15 (lima belas) perusahaan yang menjadi mitra program pemberdayaan ini. Dengan demikian, ke depan, program ini diharapkan bisa dikembangkan lebih lanjut dengan mengikutsertakan banyak pihak dalam rangka mengurangi jumlah pengangguran bagi kaum muda di Jawa Timur.

\section{UCAPAN TERIMAKASIH (Bila ada)}

Ucapan terimakasih disampaikan kepada Kamar Dagang dan Industri Provinsi Jawa Timur dan PT. Plan Indonesia yang telah mengikutsertakan penulis sebagai Tim Pelaksana Teknis dalam kegiatan ini selama 3 (tiga) tahun secara berturut-turut, tahun 2012-2015.

\section{REFERENSI}

Andi Haris et.al. (2014), Memahami Pendekatan Pemberdayaan Masyarakat Melalui Pemanfaatan Media, Jupiter, Vol. XIII No.2, h.5062

Adisasmita, Rahardjo (2006) Pemabngunan Pedesaan dan Perkotaan, Yogyakarta, Graha Ilmu
Agustus 2012 Tingkat Pengangguran Terbuka Jatim 4,12 Persen, diunduh tanggal 11 September 2019 dari <http://kominfo.jatimprov.go.id/read/umum/33102>

Disnaker Jatim Klaim Turunkan Pengangguran Terbuka, diunduh tanggal 11 September 2019 dari <https://jatim.antaranews.com/berita/117379/disnakerjatim-klaim-turunkan-pengangguran-terbuka>

Helmy Shoim Pramudyarto (2017), Kepemimpinan Pemuda dalam Pemberdayaan Masyarakat Untuk Meningkatkan Ketahanan Ekonomi Keluarga (Studi Kepemimpinan Wawan Yuanda di Desa Tumiyang, Kecamatan Kebasen, Kabupaten Banyumas, Provinsi Jawa Tengah), Jurnal Ketahanan nasional, Volume 23, No.1, ISSN 0853-9340 (Print), ISSN 2527-9088 (online)

Garis Kemiskinan Menurut Provinsi 20132015, BPS diunduh tanggal 10 September 2019 dari <bappenas.go.id/download.php?id=8629>

Jati, N Dewanto (2012) Pemberdayaan Pemuda melalui Proses Rehabilitasi Korban Penyalahgunaan Narkoba di Lembaga Panti Sosial Pamardi Putra (PSPP), Yogyakarta

Maani, Karjuni Dt (2011). Teori ACTORS dalam Pemberdayaan Masyarakat, Demokrasi, Volume X, No.1

Mustangin et.al. (2017) Pemberdayaan Masyarakat Berbasis Potensi Lokal Melalui Program Desa Wisata di Desa Bumiaji, Jurnal Pemikiran dan Penelitian Sosiologi Sosioglobal, h.59-72

Rasyad, A \& Suparna, B (2003) Pengembangan dan Pemberdayaan Masyarakat, Malang, UM Pers

Tingkat Pengangguran Terbuka Jatim Turun, diunduh tanggal 11 September 2019 dari <http://kominfo.jatimprov.go.id/read/umum/35202>

Wibawa, A (2014) Pemberdayaan Masyarakat dalam Rehablitasi Hutan Melalui Program Kebun Bibit Rakyat di Desa Sumberejo Kecamatan Tempel Kabupaten Sleman, Jurnal Pemabngunan Wilayah dan Kota, Vol 10 (2), h.187196

Yunus Winoto dan Tine Silvana Rachmawati (2017), Pemberdayaan Masyarakat (Community Empowerment) Melalui Penyelenggaraan Taman Bacaan Masyarakat Ekonomi, Sosial, dan Budaya $\quad 1417$ 
Prosiding PKM-CSR, Vol. 2 (2019)

e-ISSN: 2655-3570

(TBM), Prosiding Seminar Nasional Pendidikan

FKP UNTIRT, ISBN 978-602-19411-2-6 